\title{
The Necessity of Low-carbon Economic Indicators into The Government Performance Evaluation Index System
}

\author{
Jiang Ning ${ }^{1}$ \\ ${ }^{1}$ School of Humanities and Social Science, North China Electric Power University, Beijing 102206, \\ China
}

Keywords: Low-carbon Economy; Government Performance; Assessment Indicators; Scientific Concept of Development

\begin{abstract}
Low-carbon economy is becoming the trend of world economic development, countries are gradually promote the transformation of social economic development. In the economic development mode shift from the traditional mode to the low-carbon mode process, to re-examine the objective requirements of Local Government Performance Evaluation System. Government performance is one of the important objectives of government reform, the key of government performance management is a scientific government performance evaluation index. At present, there exist some deviations in the performance evaluation index elements of local government such as excessive pursuit of economic growth, qualitative and quantitative assessment indicators set unreasonable, undue emphasis on performance indicators, as well as refinement of unified index system and other deviations. Low-carbon economic indicators and trends in terms of value-oriented performance evaluation is an important role. This article will examine the necessity of a low carbon economy targets into government performance system reform in government performance evaluation index system.
\end{abstract}

\section{Introduction}

Study on Government Performance Evaluation System was originally from Western countries. We will get different definitionsfrom different angles to understand government performance.Compel (1993), who proposed performance evaluation is the result of the activity itself and not activities, its claim is a quantifiable performance behavior [1]. While kathryn E. Newcomer (1997) that the performance evaluation is an attempt to calm, objective evaluation of the effect generated by the project [2].Government performance is one of the important objectives of government reform, government performance evaluation index is the key scientific government performance management. At present, the performance evaluation index elements of local government there is excessive pursuit of economic growth, qualitative and quantitative assessment indicators set unreasonable, undue emphasis on performance indicators, as well as refinement of unified index system and other deviations. In the development of the situation of low-carbon economy, government performance evaluation index system should conform to the requirements of low-carbon economic development trends and make the appropriate adjustments.

\section{Low-carbon Economy Is the Trend of Social Development and Economic Development}

"Low carbon economy" was first found in the government documents in 2003 UK Energy White 
Paper "Our energy future: Creating a low-carbon economy". Low-carbon economy based on the characteristics of the target to reduce greenhouse gas emissions and build low energy consumption, low pollution-based economic development system. Dating back to 1992, "the United Nations Framework Convention on Climate Change," and the 1997 "Kyoto Protocol", clearly show that the world has recognized the grim situation of the world's environment and energy, the United Kingdom, Germany, the United States, Japan and other countries among the first to take a series of measures to transform the economic development mode, development of low-carbon economy has achieved some success, of course, China also closely follow the world trend, according to China's specific national conditions, from the ideological consciousness to all aspects of the planning, to the establishment of the experimental area, and comprehensively promote the development of low carbon economy.

Low-Carbon Economy in Energy Conservation and Improving Energy Efficiency Can Play A Good Effect. Low-carbon economy through technological innovation, system innovation, industrial restructuring, new energy development and other means to minimize coal, oil and other carbon energy consumption and reduce greenhouse gas emissions and achieve economic and social development and environmental protection, a win-win economic development patterns.

It is a direct result of the energy efficiency of technological innovation brought in a low carbon economy requirements to reduce energy consumption, improve energy efficiency interest rate, for consuming as little energy to produce as much energy efficiency. NengxiaoXuan (2004) compared the national energy efficiency, combined with China's national conditions to analyze and compare the results, concluded that: the use of advanced technology, improve equipment and management level, and the establishment of energy-saving society, for now is an important measure of energy efficiency, effectively tap the energy potential [3].

Liberation Daily (2009) published a story: McKinsey Global Institute study in 2009 showed that, the best way to reduce emissions is to improve energy efficiency from every point of view. If according to the current carbon emissions by 2020, the global average will produce 70 billion tons of carbon emissions annually. But if energy efficiency, It will be able to reduce carbon emissions by 14 billion tons per year, the supply of low-carbon energy sources will reduce carbon emissions by 12 billion tons per year, land carbon sinks could reduce carbon emissions by 12 billion tons per year, the decrease in the annual change in consumer behavior carbon emissions is less than any of the first three [4].

From the articles, we can get the conclusion that, developing low carbon economy plays an important role in promoting mutual to achieve energy saving and to achieve improved energy efficiency in the field of energy.

\section{Low-carbon Economy Is the Direction of the Government Performance Evaluation Index System Reform}

There is A Contradiction between Traditional Government Performance Evaluation Index and Low-Carbon Economy. Traditional local government performance evaluation system too much emphasis on economic indicators, the number of significant performance indicators and targets, excessive pursuit of total economic growth, the size and speed, ignoring the quality and cost of economic development - efficiency, environmental protection and resource utilization efficiency and other indicators contempt process indicators, potential targets, soft targets, resulting in an increase growth in the waste of resources, environmental pollution, ecological degradation, social injustice, social conflicts and other problems [5].

Therefore, the traditional performance evaluation index system of government must reassert 
itself in a low-carbon economic development perspective.

Low-carbon Economy in Line with the Scientific Development Concept and the Correct View of Achievements. The idea of low-carbon economy in line with the requirements of the scientific concept of development. Developing low-carbon economy to achieve scientific development both social and economic, as well as material needs and ecological needs of the people, and the development of a low carbon economy is to coordinate the development of eco-economic response to climate change specific performance, to achieve ecological and economic construction and coordinated development, in line with the inherent requirements of comprehensive development. We know that in overall harmonious development between man and nature co-ordinate domestic development and opening-up, and pay special attention to the relationship between man and nature. And the development of the core issue of the relationship between man and nature is the development of the relationship between ecology and economy. And critical natural harmonious development co-ordinator, is to coordinate the relationship between ecological protection and economic development, it would need to develop a low-carbon economy [6].

Therefore, Xiaochun Chen (2012) has proposed that In the low-carbon economic development model, "harmony between man and nature" and "ecological security" has become a new value orientation of government action, the focus will shift government functions develop low-carbon economy and build up low-carbon society. Thus, government performance evaluation, the "low carbon targets" should be added to evaluate the ability of governments to reduce carbon emissions [7].

Low-carbon economy in line with the requirements of the correct view of achievements. Developing Carbon economy, changing the economic development of the ultimate goal is the protection of the health and safety of the people, safeguard people's fundamental interests, to achieve a comprehensive harmonious and sustainable development of human society, economy and environment, the concept of "public standard" value orientation , adhere to the people-oriented, the fundamental interests of the people all work as the starting point and end point, and continuously meet the various needs of the people and achieve comprehensive human development, is the fundamental value orientation under the socialist market economy of local Government performance evaluation [8].

\section{References}

[1] Compell,J.P,et, A theory of performance In Schmitt,et,aledit personnel selection in organization[M].Jessey-bass publishers,san Francisco,1993.

[2] Kathryn E.Newcomer.Using Performance Management to Improve Public ang Nonprofit Programs[J].san Francisco,California:Jossey-Bass inc,1997,(1):7.

[3] XuanXiaoneng. China's energy efficiency analysis. International Petroleum Economics. 2014,(9) Vol. 12, No. 9: 39

[4] Tang Ye.The best way to reduce carbon emissions: energy efficiency, Liberation Daily 014 version of the new Financial Weekly World Economy • December 12, 2009

[5] XuYanping andTang Ling.Low-carbon economic development in sight of Local Government Performance Evaluation System Remodeling, Journal of Xiangtan University (Philosophy and Social Sciences), January 2014 Vol. 38, No. 1: 104

[6] Huang Juan, Yang Lei and Yang Hui. On the scientific concept of development and low-carbon economy, management science, in June 2011 Volume 24, No. 3: 36

[7] Chen Xiaochun, WangXiaoyan. Study of government performance evaluation system under the 
low carbon perspective, Chinese administration, 201210 Total No. 328: 67

[8] PengGuofu. Local Government Performance Evaluation,firsted.Hunan China. 2005 